\title{
Serum Ferritin Concentration in Corona Virus Disease 19
}

\author{
Samir Singh, ${ }^{1}$ Sujit Kumar Darnal, ${ }^{2}$ Arun Bahadur Chand ${ }^{3}$ \\ ${ }^{1}$ Department of Clinical Biochemistry, KIST Medical College, Imadol, Lalitpur, Nepal; \\ ${ }^{2}$ KIST Medical College, Imadol, Lalitpur, Nepal; \\ ${ }^{3}$ Department of Clinical Laboratory Services, KIST Medical College, Imadol, Lalitpur, Nepal.
}

\begin{abstract}
Introduction: Coronavirus disease 19 (COVID-19) is a complex disease responsible for the development of exacerbated inflammatory response (cytokine storm) that ultimately leads to multiorgan failure and death. Serum ferritin has been recently identified as one of the inflammatory markers responsible for the pro-inflammatory effects. Small amount of ferritin is present in plasma (15-150 ng/mL) which might increase with the severity of COVID-19. Therefore, measurement of ferritin is essential in identifying disease severity and predict disease prognosis.

Objective: This study aims to assess the ferritin level in COVID-19 patients.

Methods: A cross-sectional study was carried out on 259 COVID-19 patients visiting KIST Medical College and Teaching Hospital (KISTMCTH), Lalitpur, Nepal from November 2020 to April 2021. Serum ferritin was estimated in the automated Siemens ADVIA Centaur CP Chemiluminescence Immunoassay system. All the patients visiting KISTMCTH referred by clinician for ferritin assessment were included in this study. Data collected using the proforma tool was tabulated in SPSS 21 and statistical analysis was done by inferential statistical test.

Results: Out of total 259 COVID-19 patients, $58.7 \%$ were male and the majority of patients (82.6\%) were below 70 years of age. The mean age for all participants was $52.11 \pm 16.59$ years. Hyperferritinemia was seen in 218 (84.16\%) COVID -19 patients. The mean value of serum ferritin was $767.1 \pm 789.86$ (IQR: $12.8-4590) \mathrm{ng} / \mathrm{mL}$ and was significantly higher in males $(\mathrm{p}<0.001$ ). Comparing the mean values of ferritin between the patients below and above 70 years, no statistical difference was observed $(\mathrm{p}=0.872)$.
\end{abstract}

Conclusions: In our study, serum ferritin levels were greatly increased in patients with COVID-19 infection.

Keywords: Coronavirus disease 19; cytokine storm; inflammatory marker; serum ferritin.

\section{INTRODUCTION}

Coronavirus disease 19 (COVID-19) is a viral infection caused by newly discovered corona virus; variant of severe acute respiratory syndrome coronavirus 2 (SARS-CoV-2), which was first found in Wuhan, China in 2019. ${ }^{1-3}$ Most people infected with the COVID-19 virus may experience mild to moderate respiratory illness and recover

\section{Correspondence \\ Dr. Samir Singh \\ Email: samirbiochem.jnu@gmail.com

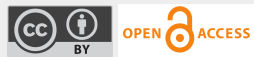 \\ Citation \\ Singh S, Darnal SK, Chand AB. Serum Ferritin Concentration in Corona Virus Disease 19. Nepal J Health Sci. 2021 Jul-Dec; 1(2): 34-7.}

spontaneously without aid of treatment. Older people and patients with comorbidities like cardiovascular disease, diabetes, chronic respiratory disease, and cancer are more prone to develop serious illness. ${ }^{4}$

Ferritin is an intracellular protein that binds with iron and helps store iron in the body and has been long studied as a marker of iron metabolism. ${ }^{5}$ The normal range of ferritin in serum is between $15 \mathrm{ng} / \mathrm{mL}$ and $150 \mathrm{ng} / \mathrm{mL} .{ }^{6}$ Ferritin is also recognized as a biomarker of inflammation and is responsible for immune suppression and uncontrolled pro-inflammatory effects, contributing to the cytokine storm. ${ }^{7,8}$ In order to limit severe complications and eventual death, the early identification of COVID-19 patients 
with negative prognostic factors might be useful in the management strategy. ${ }^{9}$ Many individuals with diabetes and possibly other disorder like thrombotic disease and cancer exhibit elevated serum ferritin levels, and they are liable to experience serious complications from COVID-19. ${ }^{10-12}$ Macrophages release inflammatory cytokine like Interleukins 6 (IL-6), IL-10, and tumor necrosis factor $\alpha$ (TNF- $\alpha$ ) which is increased in patients with severe COVID-19 disease, resulting in cell damage to the lungs and other organs. Serum ferritin has been recently cited as one of the indicators of mortality in COVID-19 patients. ${ }^{13-15}$ Therefore, measurement of ferritin is crucial in identifying disease severity and foresees disease prognosis. ${ }^{16}$ The objective of this study is to assess the level of ferritin in COVID-19 patients admitted to tertiary care hospital.

\section{METHODS}

This is a cross-sectional study carried out on 259 patients with SARS-CoV-2 infection, based on a real-time reverse transcriptase-polymerase chain reaction (RT-PCR) test on throat and nasopharyngeal swab, visiting KIST Medical College and Teaching Hospital (KISTMCTH), Lalitpur, Nepal. This study was approved by the Institutional Review Committee (IRC) of KISTMCTH (Ref. No.: 077/78/46). Informed consent was obtained from all the patients.
Patients who did not give the consent were excluded out from the study.

All the patients visiting KISTMCTH referred by clinician for ferritin assessment were included in this study. Prospective data from COVID-19 patients were collected for the duration of 6 months from $1^{\text {st }}$ November 2020 to $30^{\text {th }}$ April 2021 as referred by the treating physician. For the estimation of serum ferritin levels, $3 \mathrm{ml}$ of venous blood sample was drawn in a gel tube and serum was separated by centrifuge at $3000 \mathrm{rpm}$ for 5 minutes. Serum ferritin was estimated in the automated Siemens ADVIA Centaur CP Chemiluminescence Immunoassay (CLIA) system.

Convenience sampling method was used for sample collection from the COVID-19 patients. Data collected using proforma tool was tabulated in SPSS 21 and statistical analysis was done by independent t-test which is an inferential statistical test. The p-value was set at 0.05 .

\section{RESULTS}

A total of 259 COVID-19 patients were included in the study. The mean age for all patients was $52.11 \pm$ 16.59 years ranging from 11 to 88 years. Majority of the patient were male $(58.7 \%)$ as shown in Table 1.

Table 1: Distribution of COVID-19 patients according to sex.

\begin{tabular}{|l|c|c|}
\hline \multicolumn{1}{|c|}{ Sex } & Number (N) & Percentage (\%) \\
\hline Male & 152 & $58.7 \%$ \\
\hline Female & 107 & $41.3 \%$ \\
\hline Total & 259 & $100 \%$ \\
\hline
\end{tabular}

Regarding the distribution of patients with COVID-19, $82.6 \%$ of patients were below 70 years and $17.4 \%$ were 70 years and above. (Figure 1)

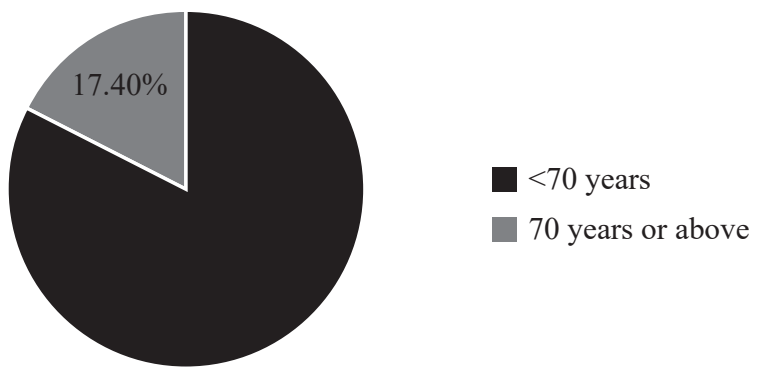

Figure 1: Distribution of COVID-19 patients according to age group 
Table 2: Comparison of demographic characteristics and serum ferritin concentration in COVID-19 patients.

\section{Number (n)}

Mean (ng/mL)

Standard deviation

p value

\begin{tabular}{|l|c|c|c|c|}
\hline Age, years & \multicolumn{5}{l|}{} \\
\hline$<70$ years & 214 & 770.74 & 804.91 & 0.872 \\
\hline 70 years and above & 45 & 749.79 & 722.16 & $<0.001$ \\
\hline Sex & 152 & 927.02 & 865.44 & 602.32 \\
\hline Male & 107 & 539.94 & & \\
\hline Female &
\end{tabular}

Hyperferritinemia was seen in 218 (84.16\%) COVID-19 patients. The mean value of serum

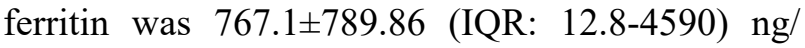
$\mathrm{mL}$. This high variability in the data of ferritin value was due to the vast differences in the high $(4590 \mathrm{ng} /$ $\mathrm{mL})$ and low $(12.8 \mathrm{ng} / \mathrm{mL})$ values of ferritin level obtained in COVID-19 patients. The mean value of serum ferritin in males $(927.02 \pm 865.44 \mathrm{ng} / \mathrm{mL})$ was significantly higher as compared to the mean value $(539.94 \pm 602.32 \mathrm{ng} / \mathrm{mL})$ of females $(\mathrm{p}<0.001)$. Comparing the mean values of ferritin between the patients below and above 70 years, no statistical difference was observed $(\mathrm{p}=0.872)$ which was shown in Table 2.

\section{DISCUSSION}

SARS-Cov-2 induces an abnormal immune and inflammatory reaction due to the infiltration of many immune cells resulting in the manifestation of a cytokine storm, including the expression of proinflammatory cytokines. This leads to increased inflammation that causes cell damage and the release of ferritin. ${ }^{17,18}$

In the present study, the demographic characteristics of the COVID-19 patients were studied. The average age of the patients was $52.11 \pm 16.59$ years. Similar results were obtained in various studies done by the different group of researchers. ${ }^{19,20}$ But the study was done in Karnataka, India by Rajanna et al. revealed the average age of their study patients to be $43.89 \pm 15.58$ years which was lesser than our study. ${ }^{21}$ Our study has demonstrated high percentage of males $(58.7 \%)$ as compared to females. In concurrence with our findings, several studies conducted in different part of the world have observed the male preponderance in COVID-19 patients. $^{8,}$ 14, 19, 22 Females are less prone to viral infections. This reduced susceptibility of females could be attributed to the protection from $\mathrm{X}$ chromosome and sex hormones, which play an important role in innate and adaptive immunity. ${ }^{23}$

This study found that $218(84.16 \%)$ of the COVID-19 patients had increased serum ferritin levels $(>150 \mathrm{ng} /$ $\mathrm{mL}$ ) i.e. hyperferritinemia. Ferritin is a key mediator of immune dysfunction, more specifically when there is hyperferritinemia, via direct immune-suppressive and pro-inflammatory effects, terminating to the cytokine storm. $^{7}$ The mean values of serum ferritin in patients below and above 70 years were $770.74 \pm 804.91$ and $749.79 \pm 722.16$ respectively. From these findings, we had observed that the mean values of serum ferritin in both groups were similar and there was no statistical difference $(p=0.872)$ according to age group. In our study, the mean value of serum ferritin in males $(927.02 \pm 865.44 \mathrm{ng} / \mathrm{mL})$ was higher as compared to females $(539.94 \pm 602.32$ $\mathrm{ng} / \mathrm{mL}$ ) therefore, we found significant differences in ferritin concentrations between males and females COVID-19 patients $(p<0.001)$. The exact mechanism of the gender difference in ferritin level is unknown. It may be due to the high prevalence of iron deficiency in female. In male, serum ferritin levels tended to increase sharply with progression to puberty whereas in female the serum ferritin levels remained constant until age 14 years and decreased thereafter. ${ }^{24}$

\section{CONCLUSIONS}

In conclusion, the current study showed that serum ferritin concentrations were greatly increased in most of the COVID-19 patients. Our findings suggest the 
use of serum ferritin as a marker for COVID-19 infection.

\section{ACKNOWLEDGEMENT}

\author{
We are thankful to KIST Medical College and \\ Teaching Hospital, Lalitpur, Nepal for providing
}

ethical approval and research work. We also thank to the clinical laboratory services staffs for their valuable support to complete this work.

\section{Conflict of Interest: None}

\section{REFERENCES}

1. Keski H. Hematological and Inflammatory Parameters to Predict the Prognosis in COVID-19. Indian J Hematol Blood Transfus. 2021 Feb 27;37(4):1-9. doi: 10.1007/s12288-021-01407-y. Epub ahead of print. PMID: 33679013; PMCID: PMC7910775.

2. Chen N, Zhou M, Dong X, Qu J, Gong F, Han Y, Qiu Y, Wang J, Liu Y, Wei Y, Xia J, Yu T, Zhang X, Zhang L. Epidemiological and clinical characteristics of 99 cases of 2019 novel coronavirus pneumonia in Wuhan, China: a descriptive study. Lancet. 2020 Feb 15;395(10223):507-513. doi: 10.1016/S0140-6736(20)302117. Epub 2020 Jan 30. PMID: 32007143; PMCID: PMC7135076.

3. Wei-jie W, Zheng-yi N, Yu H, Wen-hua L, Chun-quan O, Jian-xing H, et al. Clinical characteristic of coronavirus disease 2019 in china. NEJM group public health emergency collection. 2020;328:1708-20. DOI: https://doi.org/10.1056/NEJmoa2002032

4. Jonathan F, Douglas T, Santiago T, Alaina K, Leonard N. Ferritin level in patient with covid19: a poor predictor of mortality and haemophagocyticlymphocytosis International journal of laboratory hematology. 2020;42(6):773-9. DOI: https://doi.org/https//doi.org/11.11/ijlh.13309

5. Kell DB, Pretorius E. Serum ferritin is an important inflammatory disease marker, as it is mainly a leakage product from damaged cells. Metallomics. 2014 Apr;6(4):748-73. doi: 10.1039/c3mt00347g. PMID: 24549403

6. Lu Z, O’Dell D, Srinivasan B, Rey E, Wang R, Vemulapati S, Mehta S, Erickson D. Rapid diagnostic testing platform for iron and vitamin A deficiency. Proc Natl Acad Sci U S A. 2017 Dec 19;114(51):13513-13518. doi: 10.1073/pnas.1711464114. Epub 2017 Dec 4. PMID: 29203653; PMCID: PMC5754775.

7. Manuel VV, Christian CR. Ferritin level and covid19. Revpanamsalud publica. 2020;1(44):e72. DOI: https://doi.org/10.26633/RPSP.2020.72

8. Huang C, Wang Y, Li X, Ren L, Zhao J, Hu Y, et al. Clinical feature of patient infected with 2019 novel coronavirus in Wuhan, China. Elsevierpublic health emergency collection.2020;395(10223):497-506. DOI: https://doi.org/10.1016/S0140-6736(20)30183-5

9. Banchini, F., Cattaneo, G.M. \& Capelli, P. Serum ferritin levels in inflammation: a retrospective comparative analysis between COVID-19 and emergency surgical non-COVID-19 patients. World J Emerg Surg 16, 9 (2021). https://doi.org/10.1186/s13017-021-00354-3

10. Khalil, U.A., Seliem, F.O., Alnahal, A. et al. Association of serum ferritin with insulin resistance in offsprings of type 2 diabetics. Egypt J Intern Med 30, 13-17 (2018). https://doi.org/10.4103/ejim.ejim_70_17

11. Momeni A, Behradmanesh MS, Kheiri S, Abasi F. Serum ferritin has correlation with HbA1c in type 2 diabetic patients. Adv Biomed Res. 2015 Mar 25;4:74. doi: 10.4103/2277-9175.153900. PMID: 25878999; PMCID: PMC4386204.

12. Son NE. Influence of ferritin levels and inflammatory markers on HbA1c in the Type 2 Diabetes mellitus patients. Pak J Med Sci. 2019 Jul-Aug;35(4):1030-1035. doi: 10.12669/pjms.35.4.1003. PMID: 31372137; PMCID: PMC6659066.

13. Gómez-Pastora J, Weigand M, Kim J, Wu X, Strayer J, Palmer AF, Zborowski M, Yazer M, Chalmers JJ. Hyperferritinemia in critically ill COVID-19 patients - Is ferritin the product of inflammation or a pathogenic mediator? Clin Chim Acta. 2020 Oct;509:249-251. doi: 10.1016/j.cca.2020.06.033. Epub 2020 Jun 21. PMID: 32579952; PMCID: PMC7306200

14. Ayanian S, Reyes J, Lynn L, Teufel K. The association between biomarkers and clinical outcomes in novel coronavirus pneumonia in a US cohort. Biomark Med 2020 Aug;14(12):1091-1097. doi: 10.2217/bmm-2020-0309. Epub 2020 Jul 17. PMID: 32677844; PMCID: PMC7493720.

15. Cheng L, Li H, Li L, Liu C, Yan S, Chen H, Li Y. Ferritin in the coronavirus disease 2019 (COVID-19): A systematic review and meta-analysis. J Clin Lab Anal. 2020 Oct;34(10):e23618. doi: 10.1002/jcla.23618. Epub 2020 Oct 19. PMID: 33078400; PMCID: PMC7595919.

16. Gómez-Pastora J, Weigand M, Kim J, Wu X, Strayer J, Palmer AF, Zborowski M, Yazer M, Chalmers JJ. Hyperferritinemia in critically ill COVID-19 patients - Is ferritin the product of inflammation or a pathogenic mediator? Clin Chim Acta. 2020 Oct;509:249-251. doi: 10.1016/j.cca.2020.06.033. Epub 2020 Jun 21. PMID: 32579952; PMCID: PMC7306200

17. Deng F, Zhang L, Lyu L, Lu Z, Gao D, Ma X, Guo Y, Wang R, Gong S, Jiang W. Increased levels of ferritin on admission predicts intensive care unit mortality in patients with COVID-19. Med Clin (Barc). 2021 Apr 9;156(7):324-331. doi: 10.1016/j.medcli.2020.11.030. Epub 2020 Dec 25. PMID: 33422296; PMCID: PMC7832996.

18. Burugu HR, Kandi V, Kutikuppala LVS, Suvvari TK. Activities of Serum Ferritin and Treatment Outcomes Among COVID-19 Patients Treated With Vitamin C and Dexamethasone: An Uncontrolled Single-Center Observational Study. Cureus. 2020;12(11):e11442. DOI: https://oi.org/10.7759/cureus.11442

19. Lino K, Guimarães GMC, Alves LS, Oliveira AC, Faustino R, Fernandes CS, Tupinambá G, Medeiros T, Silva AAD, Almeida JR. Serum ferritin at admission in hospitalized COVID-19 patients as a predictor of mortality. Braz J Infect Dis. 2021 Mar-Apr;25(2):101569. doi: 10.1016/j.bjid.2021.101569. Epub 2021 Mar 15. PMID: 33736948; PMCID: PMC7959266.

20. Tural Onur S, Altın S, Sokucu SN, Fikri Bİ, Barça T, Bolat E, Toptaş M. Could ferritin level be an indicator of COVID-19 disease mortality? J Med Virol. 2021;93(3):1672-1677. DOI: https://doi.org/10.1002/jmv.26543.

21. Rajanna A, Krishnegowda R, Govindaiah R. (2021). To Correlate Serum Ferritin Levels with Clinical Outcome in Covid-19 Patients. Asian J. Med. Sci. 2021;12(5): 25-29. DOI: https://doi.org/10.3126/ajms.v12i5.34371.

22. Gandini O, Criniti A, Ballesio L, Giglio S, Galardo G, Gianni W, et al. Serum Ferritin is an independent risk factor for Acute Respiratory Distress Syndrome in COVID-19. J Infect. 2020;81(6): 979-997. DOI: https://doi.org/10.1016/j.jinf.2020.09.006.

23. Jaillon S, Berthenet K, Garlanda C. Sexual dimorphism in innate immunity. Clin Rev Allerg Immunol. 2019;56:308-21. DOI: https://doi.org/10.1007/s12016-017-8648-x

24. Oh HL, Lee JA, Kim DH, Lim JS. Reference values for serum ferritin and percentage of transferrin saturation in Korean children and adolescents. Blood Res. 2018;53(1):18-24. DOI: https://doi.org/10.5045/br.2018.53.1.18. 